\title{
Comparison of male reproductive parameters in mice with type 1 and type 2 diabetes
}

\author{
Apichakan Sampannang', Supatcharee Arun', Jaturon Burawat' ${ }^{1}$, Wannisa Sukhorum ${ }^{2}$, Sitthichai lamsaard ${ }^{1,3}$ \\ 'Department of Anatomy, Faculty of Medicine, Khon Kaen University, Khon Kaen; ${ }^{2}$ Department of Anatomy, School of Medicine, Mae Fah Luang \\ University, Chiang Rai; ${ }^{3}$ Research Institute for Human High Performance and Health Promotion, Khon Kaen University, Khon Kaen, Thailand
}

\begin{abstract}
Objective: The differences between type 1 and type 2 diabetes mellitus (T1DM and T2DM) in terms of their adverse effects on male reproductive parameters have never been elucidated. This study aimed to distinguish between the effects of the DM types in mice treated with multiple low doses of streptozotocin (STZ) to mimic human T1DM and coadministered a high-fat diet (HFD) to mimic human T2DM.

Methods: The T1DM mice were intraperitoneally injected with STZ ( $40 \mathrm{mg} / \mathrm{kg}$ body weight) for 5 days. The T2DM mice received an HFD for 14 days prior to STZ injection ( $85 \mathrm{mg} / \mathrm{kg}$ body weight), followed by continuous feeding of an HFD. Male reproductive parameters were evaluated. Results: The reproductive organs of the DM mice weighed significantly less than those of controls, and the seminal vesicles plus prostates of the T1DM mice weighed less than those of the T2DM mice. Increased sperm abnormalities and incomplete DNA packaging were observed in the DM groups. Sperm concentration and the proportion of normal sperm were significantly lower in the T1DM group. The seminiferous histopathology of DM mice was classified into seven types. The penises of the DM mice were smaller than those of the controls; however, tunica albuginea thickness and the amount of penile collagen fibers were increased in these mice. Round germ cells were abundant in the epididymal lumens of the mice with DM.
\end{abstract}

Conclusion:T1DM adversely affected reproductive parameters to a greater extent than T2DM.

Keywords: Mice; Sperm; Streptozotocin; Type 1 diabetes mellitus; Type 2 diabetes mellitus

\section{Introduction}

The worldwide prevalence of both type 1 and type 2 diabetes mellitus (T1DM and T2DM, respectively) is rapidly increasing [1,2]. Various disorders can result from T1DM and T2DM, including male repro-

Received: July 1, 2019 · Revised: September 17, 2019 · Accepted: September 18, 2019 Corresponding author: Sitthichai lamsaard

Department of Anatomy, Faculty of Medicine, Khon Kaen University, Khon Kaen 40002, Thailand

Tel: +66-852896363 Fax:+66-43202426

E-mail: sittia@kku.ac.th

*Financial support for this research was provided by an Invitation Research Grant (IN60205), Faculty of Medicine, Khon Kaen University, awarded to Dr. Apichakan Sampannang and associate professor Dr. Sitthichai lamsaard, which was granted by the Performance \& Health Promotion (HHP\&HP) Research Institute of Khon Kaen University.

This is an Open Access article distributed under the terms of the Creative Commons Attribution Non-Commercial License (https://creativecommons.org/licenses/by-nc/4.0/) which permits unrestricted non-commercial use, distribution, and reproduction in any medium, provided the original work is properly cited. ductive dysfunction [3-8]. Diabetes mellitus has also been found to alter glucose metabolism in Sertoli cells, decrease spermatogenesis, damage testicular structure, and reduce testosterone levels [8-13]. However, the adverse effects of T1DM and T2DM on reproductive parameters have never been compared. The acrosome reaction is a specialized exocytotic process involved in the fusion and fenestration of sperm plasma and the outer acrosomal membrane after binding to the zona pellucida, resulting in an explosion of hydrolytic enzymes [14]. A precocious acrosome reaction in the epididymis and female reproductive tract is a cause of male infertility. Sperm parameters indicative of male fertility include concentration, viability, and motility [15]. Abnormal sperm morphology (either head or tail) has a direct effect on natural fertilization $[15,16]$. Additionally, the lysine-rich histones are replaced by testis-specific nuclear proteins before transforming into protamines to compact sperm chromatin [17]. Therefore, the decondensation and incomplete DNA packaging of mature sperm are potential indicators of sperm damage $[17,18]$. 
Several studies have induced DM in animal models to investigate the mechanisms of DM-related male infertility [19-23]. For T1DM, administration of multiple low doses of streptozotocin (STZ) has been used to induce subtoxic effects on $\beta$-cells, resulting in autoimmune insulitis [19,23-25]. For T2DM, STZ induction combined with a highfat diet (HFD) is commonly used to mimic human T2DM [20,21,26,27]. Although several studies have compared the effects of each DM type on male fertility, such an investigation has yet to be conducted along with the examination of essential parameters. The respective effects of each DM type on representative histological and physiological parameters in sperm, such as acrosome status and chromatin structure, have never been compared. This study thus compared T1DM and T2DM mice with regard to sperm quality and the histopathology of the testis, epididymis, and penis.

\section{Methods}

This experiment was approved by the Animal Ethics Committee of Khon Kaen University based on the Ethics of Animal Experimentation as determined by the National Research Council of Thailand (No. 0514.1.75/90 with record No. AEKKU-NELAC 71/2559).

\section{Animals and induction of diabetes}

Fifty-six male C57BL/6 mice were purchased from Nomura Siam International Co., Ltd., Bangkok, Thailand. All mice were housed within ventilated cages in a specific pathogen-free room at a constant temperature $\left(23^{\circ} \pm 2^{\circ} \mathrm{C}\right)$ under a 12-hour light-dark cycle at the Northeast Laboratory Animal Center of Khon Kaen University in Khon Kaen, Thailand. The animals were divided into four groups: (1) control for T1DM, (2) T1DM (multiple low doses of STZ [MLD-STZ]), (3) control for T2DM, and (4) T2DM (HFD cotreated with STZ [HFD-STZ]), with 14 for each group. Before the experiment, the mice were starved for 16 hours. The control mice for the T1DM group were intraperitoneally injected with $0.1 \mathrm{M}$ citrate buffer ( $\mathrm{pH} 4.5$ ) for 5 consecutive days, whereas the T1DM mice were induced with STZ (Sigma-Aldrich, St. Louis, MO, USA) at a dose of $40 \mathrm{mg} / \mathrm{kg}$ body weight (BW) for 5 consecutive days [19]. The control mice of the T2DM group received a normal diet (10 kcal\% fat, D12450J; Research Diets, New Brunswick, $\mathrm{NJ}$, USA) for 14 consecutive days before they were starved and then injected with citrate buffer. The T2DM mice received an HFD (60 kcal\% fat, D12492, Research Diet) for 14 consecutive days and were then induced with a single dose of STZ of $85 \mathrm{mg} / \mathrm{kg}$ BW $[20,21]$ followed by continuous feeding with an HFD as previously described [26-28]. On days $3,6,12,18,24,30,36,42,48,54,60,66$, and 72 , the mice in both DM groups were assessed for actual DM induction using a blood glucose oxidase reaction monitoring system with blood from a tail prick. Mice were considered to have DM when their blood glucose levels were greater than $250 \mathrm{mg} / \mathrm{dL}$. All animals were treated for 36 or 72 days (one or two spermatogenesis cycles, [29]).

\section{Morphological studies}

After euthanasia, the testes, epididymis plus vas deferens, seminal vesicle plus prostate glands, and penis were collected. The fat pads surrounding these organs were removed before weighing. The gross morphology of the organs was observed and captured using a digital camera. The penis, right testis, and epididymis were fixed with Bouin solution for 48 hours before routine paraffin embedding. The paraffinized tissue blocks were sectioned at 5-7 $\mu \mathrm{m}$ (ERM 3100 SemiAutomatic Microtome, Heston, Australia). All sections were stained with hematoxylin and eosin (H\&E) or Masson trichrome (No. HT15, Sigma-Aldrich) to observe and quantify the histopathological changes and collagen fibers. The diameters and epithelial heights of the seminiferous tubules, thickness of the tunica albuginea, cross-sectional area, and amount of collagen fibers of the penis were measured and quantified using the ImageJ program (ver. 1.50i; National Institutes of Health, Bethesda, MD, USA). The histopathology of the seminiferous tubules was classified as previously described [23]. In the epididymides, the density of sperm masses and abnormal cells on sections of the caput, corpus, and caudal parts was observed.

\section{Sperm concentration and assessment of sperm head and tail abnormality}

Sperm fluid was collected from the left caudal epididymis and vas deferens and resuspended into $1 \mathrm{~mL}$ of phosphate-buffered saline (PBS; $37^{\circ} \mathrm{C}, \mathrm{pH} 7.4$ ). The sperm suspension was subsequently centrifuged at $8,000 \times g$ for 5 minutes at $25^{\circ} \mathrm{C}$. Then, the sperm pellets were collected and resuspended in fresh PBS to be diluted (1:10) before counting the number of sperm using a Neubauer hemocytometer under light microscopy. To examine sperm head and tail abnormalities, the sperm suspension $(20 \mu \mathrm{L})$ was smeared on a glass slide in triplicate and air-dried. The dried sperm were then fixed with methyl alcohol and stained with H\&E. Six hundred spermatozoa were examined for the presence of abnormal heads and tails, as described in the study conducted by Ward [30]. Types of abnormal sperm heads included thin-elongated head $\left(\mathrm{H}_{1}\right)$, club-shaped head $\left(\mathrm{H}_{2}\right)$, and mild head defects $\left(\mathrm{H}_{3}\right)$. The classification of tail abnormalities included tailbent head $\left(T_{1}\right)$, looping midpiece $\left(T_{2}\right)$, folded midpiece and principal piece $\left(T_{3}\right)$, and incorrect head-neck connection $\left(T_{4}\right)$, respectively. The numbers of abnormal sperm heads and tails were calculated as percentages.

\section{Analysis of sperm acrosome reaction}

The sperm pellets were fixed with $4 \%$ paraformaldehyde $(\mathrm{w} / \mathrm{v})$ in PBS ( $\mathrm{pH} 7.4$ ) for 15 minutes on ice. The samples were then washed 
and resuspended with PBS. The fixed sperm were smeared on gelatin-coated slides (Unifrost Microscope Slide, Catalogue No. EMS200Wp; Azer Scientific, Morgantown, PA, USA) using a wooden stick. The dried sperm were stained with $0.22 \%$ Coomassie blue G-250 (50\% methanol, 10\% glacial acetic, 40\% water) for 2 minutes and were then washed three times with PBS before mounting with a glycerol solution (Sigma-Aldrich). Six hundred sperm from each animal were examined under a light microscope. Acrosome-intact sperm were identified by staining of their acrosomes with Coomassie blue, whereas acrosome-reacted (AR) sperm did not show staining [31,32].

\section{Evaluation of incomplete sperm DNA structure and packaging}

Toluidine blue (TB) is a metachromatic dye commonly used to evaluate sperm nuclear chromatin condensation and DNA fragmentation via binding of the phosphate groups of DNA strands [33]. Smeared sperm were fixed with $96 \%$ ethanol-acetone $(1: 1)$ at $4^{\circ} \mathrm{C}$ for 30 minutes and then hydrolyzed in $0.1 \mathrm{~N}$ hydrochloric acid at $4^{\circ} \mathrm{C}$ for 5 minutes. The slides were rinsed twice in distilled water for 2 minutes and stained with $0.05 \%$ TB in 50\% Mcllvaine citrate-phosphate buffer ( $\mathrm{pH}$ 3.5) for 10 minutes at room temperature. On each slide, 200 sperm were observed by counting the metachromatic sperm heads under light microscopy (ECLIPSE E200; Nikon, Tokyo, Japan). The unstained or pale TB-stained (negative) sperm were judged as normal-chromatin sperm, while sperm displaying intense TB staining (positive) were classified as abnormal-chromatin sperm [34].

\section{Assessment of visualization of sperm chromatin condensation}

Aniline blue $(A B)$ selectively binds to lysine-rich histones and is used for staining to demonstrate abnormalities of sperm chromatin condensation [35]. Smeared sperm was air-dried and fixed in 2.5\% glutaraldehyde buffer for 30 minutes at room temperature. Each smear was stained with $5 \%$ aqueous $A B$ solution in $4 \%$ acetic acid ( $\mathrm{pH}$ 3.5) for 5 minutes. Two hundred sperm were counted under light microscopy. Unstained or pale AB-stained (negative) sperm were considered to be sperm that had undergone normal chromatin condensation, while sperm displaying intense $A B$ staining (positive) were classified as sperm with abnormal chromatin [18,34].

\section{Statistical analysis}

To compare the differences among groups, all data were first subjected to the Shapiro-Wilk test (W-test) to confirm a normal distribution and equality of variance. One-way analysis of variance was used to compare mean values for normally-distributed data using IBM SPSS ver. 19.0 (IBM Corp., Armonk, NY, USA). The $p$-values less than 0.05 were considered to indicate statistical significance. All data were expressed as the mean \pm standard deviation.

\section{Results}

\section{Reproductive organ weight}

The reproductive organs in both DM groups (at both 36 and 72 experimental days) were clearly smaller than those of the controls (Figure 1). The weight of the testes was also significantly lower in the DM mice $(p<0.05)$ (Table 1$)$, as was that of the epididymides plus vasa deferentia in the T1DM group at 36 days and in both DM groups at 72 days $(p<0.05)$. At 72 days, the weights of these organs were significantly lower in the T1DM group than in the T2DM group $(p<0.05)$ (Table 1).

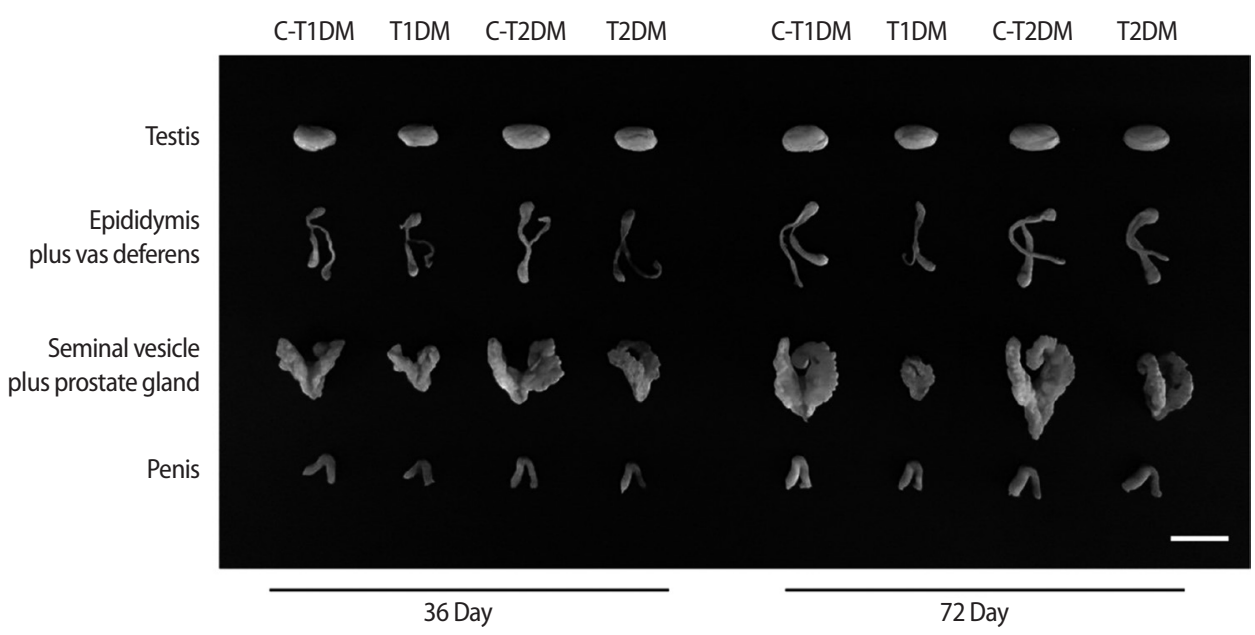

Figure 1. Representative morphological photographs of the mouse testis, epididymis plus vas deferens, seminal vesicle plus prostate gland, and penis compared among type 1 diabetes mellitus control (C-T1DM), type 1 DM (T1DM), type 2 DM control (C-T2DM), and type 2 DM (T2DM) mice on experimental days 36 and 72 . Scale bar, $1 \mathrm{~cm}$. 
Table 1. Comparison of male reproductive organ weight among C-T1DM, T1DM, C-T2DM, and T2DM mice

\begin{tabular}{|c|c|c|c|c|c|c|c|c|}
\hline \multirow{2}{*}{ Parameter } & \multicolumn{4}{|c|}{ 36 Day } & \multicolumn{4}{|c|}{72 Day } \\
\hline & C-T1DM & T1DM & C-T2DM & T2DM & C-T1DM & T1DM & C-T2DM & T2DM \\
\hline \multicolumn{9}{|l|}{ Testis } \\
\hline Absolute weight (g) & $0.096 \pm 0.003$ & $0.083 \pm 0.007^{\mathrm{a})}$ & $0.103 \pm 0.004$ & $0.084 \pm 0.012^{\mathrm{a})}$ & $0.110 \pm 0.004$ & $0.084 \pm 0.005^{\mathrm{a})}$ & $0.108 \pm 0.003$ & $0.091 \pm 0.005^{\mathrm{a})}$ \\
\hline Relative weight (g/100g) & $0.395 \pm 0.012$ & $0.442 \pm 0.037$ & $0.399 \pm 0.017$ & $0.410 \pm 0.060$ & $0.349 \pm 0.013$ & $0.422 \pm 0.026$ & $0.322 \pm 0.007$ & $0.338 \pm 0.017$ \\
\hline \multicolumn{9}{|l|}{ Epididymis plus vas deferens } \\
\hline Absolute weight (g) & $0.043 \pm 0.003$ & $0.031 \pm 0.004^{\mathrm{a})}$ & $0.050 \pm 0.008$ & $0.039 \pm 0.009$ & $0.051 \pm 0.004$ & $0.031 \pm 0.005^{\mathrm{a}, \mathrm{b})}$ & $0.049 \pm 0.001$ & $0.046 \pm 0.005^{\mathrm{a}, \mathrm{b})}$ \\
\hline Relative weight (g/100g) & $0.177 \pm 0.012$ & $0.163 \pm 0.023$ & $0.194 \pm 0.029$ & $0.188 \pm 0.042$ & $0.162 \pm 0.012$ & $0.158 \pm 0.023$ & $0.145 \pm 0.004$ & $0.170 \pm 0.019$ \\
\hline \multicolumn{9}{|c|}{$\begin{array}{l}\text { Seminal vesicle plus prostate } \\
\text { gland }\end{array}$} \\
\hline Absolute weight (g) & $0.274 \pm 0.032$ & $0.106 \pm 0.023^{\mathrm{a})}$ & $0.318 \pm 0.002$ & $0.167 \pm 0.044^{\mathrm{a})}$ & $0.375 \pm 0.017$ & $0.083 \pm 0.026^{\mathrm{a}, \mathrm{b})}$ & $0.354 \pm 0.035$ & $0.266 \pm 0.011^{\mathrm{a}, \mathrm{c}}$ \\
\hline Relative weight (g/100g) & $1.125 \pm 0.131$ & $0.565 \pm 0.120^{\mathrm{a})}$ & $1.229 \pm 0.009$ & $0.814 \pm 0.215^{\mathrm{a})}$ & $1.185 \pm 0.055$ & $0.419 \pm 0.131^{\mathrm{a}, \mathrm{b})}$ & $1.052 \pm 0.104$ & $0.991 \pm 0.039^{c}$ \\
\hline
\end{tabular}

Values are presented as mean \pm standard deviation $(n=7)$.

C-T1DM, type 1 diabetes mellitus control;T1DM, type 1 DM; C-T2DM, type 2 DM control;T2DM, type 2 DM.

Statistically significant compared to ${ }^{\text {a) }}$ the controls $(p<0.05) ;{ }^{\text {b) }}$ the T2DM group $(p<0.05) ;{ }^{\text {c }}$ the T1DM group $(p<0.05)$.

Table 2. Blood glucose levels at experimental day 36 compared among C-T1DM, T1DM, C-T2DM, and T2DM mice

\begin{tabular}{llllc}
\hline \multirow{2}{*}{ Day } & \multicolumn{4}{c}{ Blood glucose levels $(\mathrm{mg} / \mathrm{dL})$} \\
\cline { 2 - 5 } & \multicolumn{1}{c}{ C-T1DM } & \multicolumn{1}{c}{ T1DM } & \multicolumn{1}{c}{ C-T2DM } & T2DM \\
\hline 3 & $119.3 \pm 10.6$ & $367.5 \pm 92.9^{\text {a) }}$ & $169.8 \pm 29.2$ & $472.2 \pm 68.3^{\text {a) }}$ \\
6 & $133.8 \pm 7.3$ & $367.8 \pm 125.0^{\text {a) }}$ & $157.8 \pm 36.0$ & $482.1 \pm 59.1^{\text {a) }}$ \\
12 & $140.5 \pm 13.0$ & $385.2 \pm 70.8^{\text {a) }}$ & $141.4 \pm 23.7$ & $412.2 \pm 50.0^{\text {a) }}$ \\
18 & $133.0 \pm 22.2$ & $343.0 \pm 101.5^{\text {a) }}$ & $154.2 \pm 11.9$ & $433.1 \pm 47.5^{\text {a) }}$ \\
24 & $126.3 \pm 23.5$ & $383.0 \pm 68.0^{\text {a) }}$ & $169.2 \pm 15.7$ & $387.6 \pm 40.2^{\text {a) }}$ \\
30 & $139.3 \pm 27.5$ & $426.2 \pm 93.8^{\text {a) }}$ & $162.4 \pm 7.4$ & $431.2 \pm 54.9^{\text {a) }}$ \\
36 & $114.5 \pm 16.1$ & $380.2 \pm 51.9^{\text {a) }}$ & $151.6 \pm 11.7$ & $418.6 \pm 64.3^{\text {a) }}$ \\
\hline
\end{tabular}

Values are presented as mean \pm standard deviation $(n=7)$.

C-T1DM, type 1 diabetes mellitus control; T1DM, type 1 DM; C-T2DM, type 2 DM control; T2DM, type 2 DM.

a) Statistically significant compared to the controls $(p<0.05)$.

The weight of the seminal vesicles plus prostate glands in the DM groups was also significantly lower than in the control groups $(p<0.05)$ (Table 1), but did not differ significantly between DM groups.

\section{Blood glucose levels}

Blood glucose levels in both DM groups were significantly higher than in the controls at both 36 and 72 days $(p<0.05)$ (Tables 2 and 3 ).

\section{Sperm parameter analysis}

The sperm concentrations in both DM groups were significantly lower than those of controls at both 36 and 72 experimental days $(p<0.05)$ (Figure 2A). In addition, the percentages of AR sperm and incomplete DNA packaging in both DM groups were significantly higher than those of the controls $(p<0.05)$ (Figure $2 \mathrm{~B}$ and $\mathrm{C}$ ). There was a statistically significant difference in chromatin condensation among the four groups, as shown by AB staining (Figure 2D). Sperm concentrations in the T1DM group were significantly lower than in
Table 3. Blood glucose levels at experimental day 72 compared among C-T1DM, T1DM, C-T2DM, and T2DM mice

\begin{tabular}{lcllc}
\hline \multirow{4}{*}{ Day } & \multicolumn{4}{c}{ Blood glucose levels $(\mathrm{mg} / \mathrm{dL})$} \\
\cline { 2 - 5 } & C-T1DM & T1DM & \multicolumn{1}{c}{ C-T2DM } & T2DM \\
\hline 3 & $117.0 \pm 17.4$ & $390.1 \pm 66.6^{\text {a) }}$ & $133.5 \pm 7.2$ & $480.7 \pm 66.5^{\text {a) }}$ \\
6 & $130.8 \pm 10.4$ & $428.3 \pm 36.2^{\text {a) }}$ & $167.0 \pm 15.6$ & $479.4 \pm 50.3^{\text {a) }}$ \\
12 & $163.8 \pm 22.9$ & $447.0 \pm 73.1^{\text {a) }}$ & $127.5 \pm 9.7$ & $403.9 \pm 38.9^{\text {a) }}$ \\
18 & $168.8 \pm 36.1$ & $390.9 \pm 75.9^{\text {a) }}$ & $153.8 \pm 44.7$ & $399.9 \pm 43.3^{\text {a) }}$ \\
24 & $136.3 \pm 17.7$ & $416.8 \pm 86.3^{\text {a) }}$ & $131.8 \pm 34.0$ & $424.3 \pm 62.9^{\text {a) }}$ \\
30 & $139.5 \pm 16.2$ & $447.2 \pm 93.0^{\text {a) }}$ & $132.8 \pm 46.6$ & $460.0 \pm 68.0^{\text {a) }}$ \\
36 & $147.3 \pm 11.0$ & $429.8 \pm 94.0^{\text {a) }}$ & $132.8 \pm 20.5$ & $440.9 \pm 83.9^{\text {a) }}$ \\
42 & $106.3 \pm 23.4$ & $409.4 \pm 99.8^{\text {a) }}$ & $145.3 \pm 38.0$ & $501.7 \pm 88.3^{\text {a) }}$ \\
48 & $111.8 \pm 32.1$ & $386.1 \pm 100.3^{\text {a) }}$ & $117.8 \pm 26.9$ & $447.0 \pm 24.8^{\text {a) }}$ \\
54 & $143.3 \pm 24.4$ & $462.8 \pm 73.3^{\text {a) }}$ & $174.5 \pm 43.1$ & $526.3 \pm 64.1^{\text {a) }}$ \\
60 & $143.3 \pm 13.6$ & $434.7 \pm 104.8^{\text {a) }}$ & $122.5 \pm 32.4$ & $481.7 \pm 35.1^{\text {a) }}$ \\
66 & $143.5 \pm 8.9$ & $428.9 \pm 83.5^{\text {a) }}$ & $164.5 \pm 48.1$ & $582.0 \pm 25.5^{\text {a) }}$ \\
72 & $120.3 \pm 31.0$ & $449.6 \pm 75.2^{\text {a) }}$ & $102.3 \pm 13.3$ & $521.7 \pm 42.4^{\text {a) }}$ \\
\hline
\end{tabular}

Values are presented as mean \pm standard deviation $(n=7)$.

C-T1DM, type 1 diabetes mellitus control; T1DM, type 1 DM; C-T2DM, type 2 DM control; T2DM, type 2 DM.

a) Statistically significant compared to the controls $(p<0.05)$.

the T2DM group, but the percentage of AR sperm was higher in the T1DM group $(p<0.05)$ (Figure 2A and B).

A significant increase in total sperm abnormalities was observed in the DM groups $(p<0.05)$ (Figure 3$)$. As shown in Figure $4 A$, the percentage of sperm head abnormalities $\left(\mathrm{H}_{1}\right.$ or $\left.\mathrm{H}_{2}\right)$ at 36 and 72 days was significantly higher in both DM groups than in the controls (with the exception of $\mathrm{H}_{2}$ in the T1DM group at 36 days). The percentage of tail abnormalities $\left(T_{1}, T_{2}\right.$, and $T_{3}$ ) was also higher in both groups (except $T_{1}$ and $T_{3}$ in the T2DM group at 36 days and 72 days, respectively) (Figure 4B). However, no significant difference was found in the percentage of $\mathrm{T}_{4}$ abnormalities among groups (Figure 4B). 
A
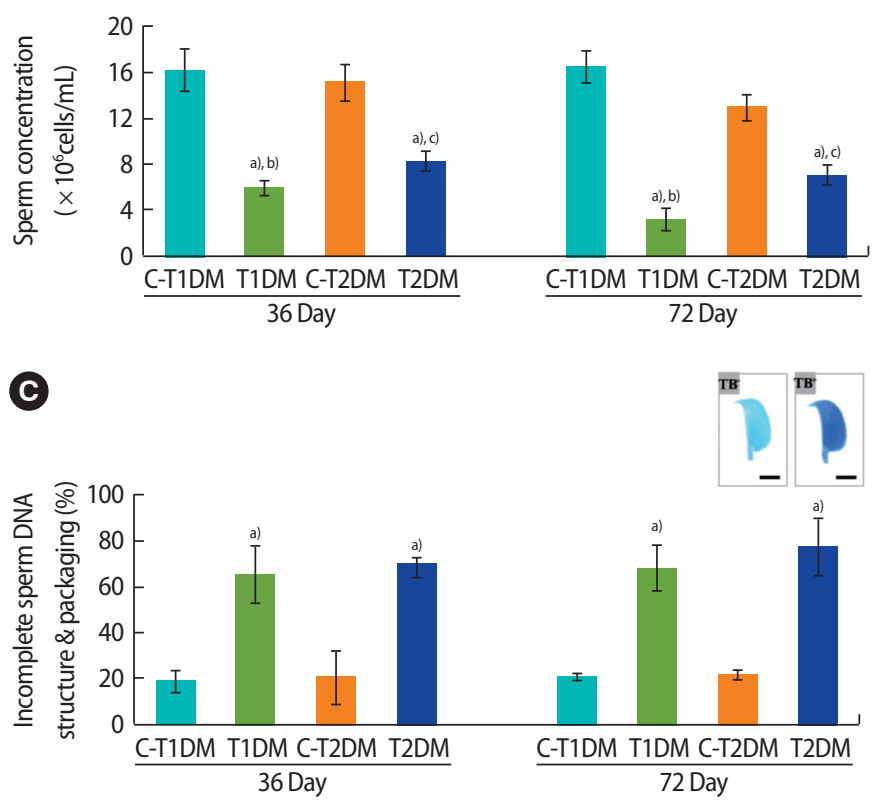

B

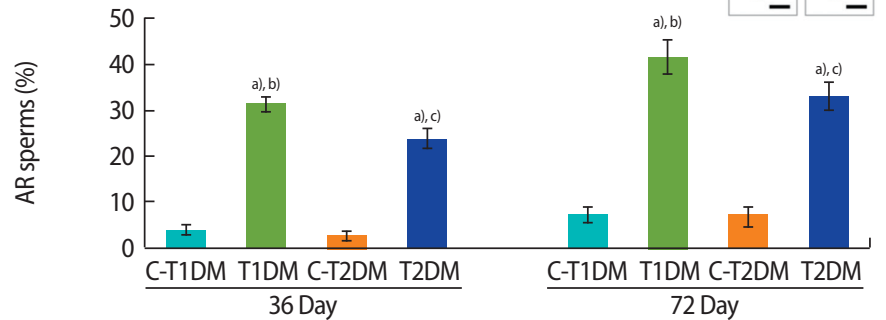

(D)

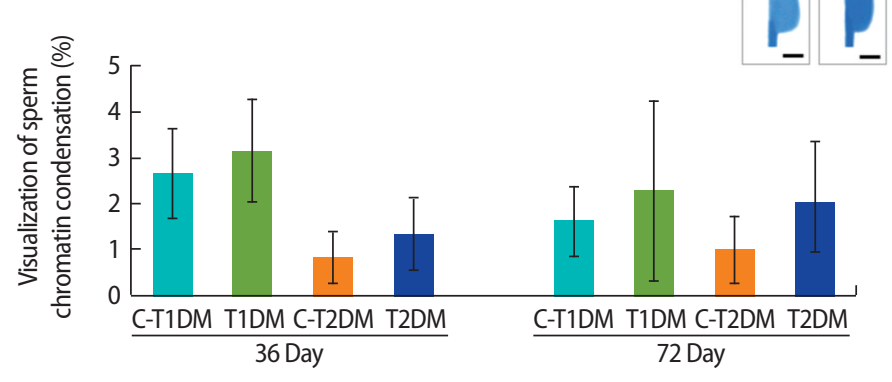

Figure 2. Comparisons among type 1 diabetes mellitus control (C-T1DM), type 1 DM (T1DM), type 2 DM control (C-T2DM), and type 2 DM (T2DM) mice on experimental days 36 and 72. (A) Sperm concentration. (B) Acrosome reaction. Top right: representative photographs of acrosome-intact (Al) sperm stained with $0.22 \%$ Coomassie blue G-250 and acrosome-reacted (AR) sperm without staining. (C) Incomplete sperm DNA structure and packaging. Top right: toluidine blue-reacted $\left(\mathrm{TB}^{+}\right)$sperm indicating sperm with abnormal chromatin versus sperm with normal chromatin $\left(\mathrm{TB}^{-}\right)$. (D) Visualization of sperm chromatin condensation. Top right: aniline blue-reacted $\left(A B^{+}\right)$sperm indicating chromatin defects of sperm nuclei versus normal sperm $\left(A B^{-}\right)$. Values are presented as mean \pm standard deviation. Scale bar, $1 \mu \mathrm{m} .{ }^{\mathrm{a})} p<0.05$ compared with control; ${ }^{\text {bl }} p<0.05$ compared with $\mathrm{T} 2 \mathrm{DM} ;{ }^{\mathrm{c}} p<0.05$ compared with T1DM.
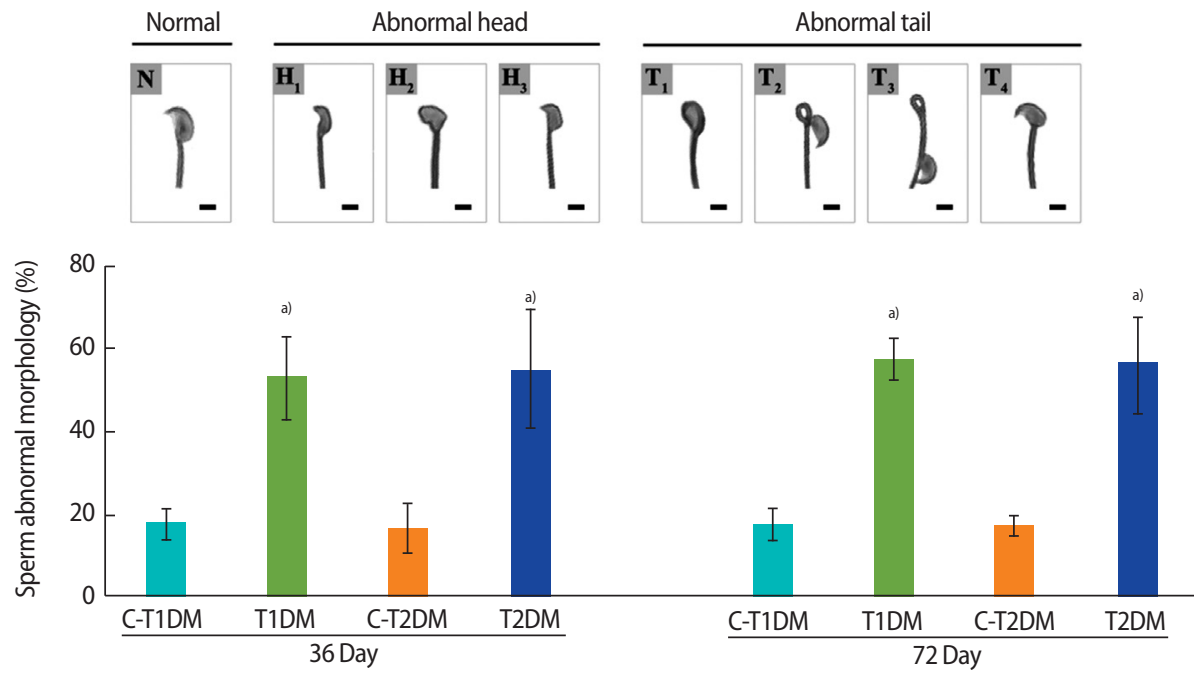

Figure 3. The percentage of total abnormal sperm morphology compared among type 1 diabetes mellitus control (C-T1DM), type 1 DM (T1DM), type 2 DM control (C-T2DM), and type 2 DM (T2DM) mice on experimental days 36 and 72 . Values are presented as mean \pm standard deviation. Scale bar, $1 \mu \mathrm{m}$. N, normal; $\mathrm{H}_{1}$, thin-elongated head; $\mathrm{H}_{2}$, club-shaped head; $\mathrm{H}_{3}$, mild head defects; $\mathrm{T}_{1}$, bent head; $\mathrm{T}_{2}$, looping midpiece; $T_{3}$, folded midpiece and principal piece; $T_{4}$, incorrect head-neck connection. ${ }^{\text {a }} p<0.05$ compared with controls.

\section{Testicular histopathology}

The percentage of total seminiferous histopathology in the DM groups was significantly higher than in the control groups $(p<0.05)$ 
A

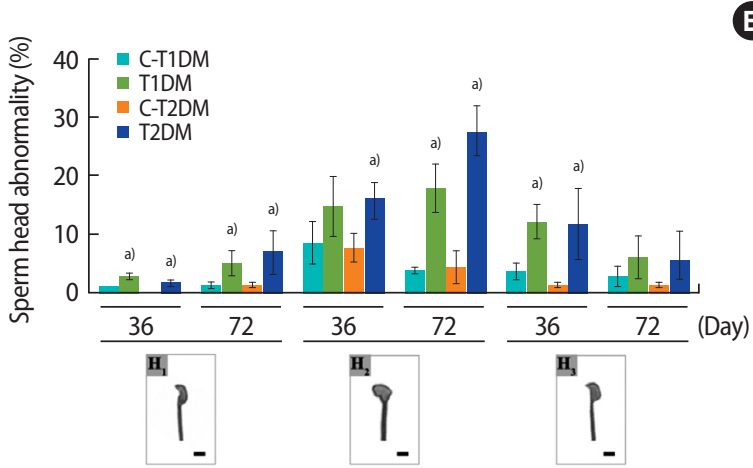

B

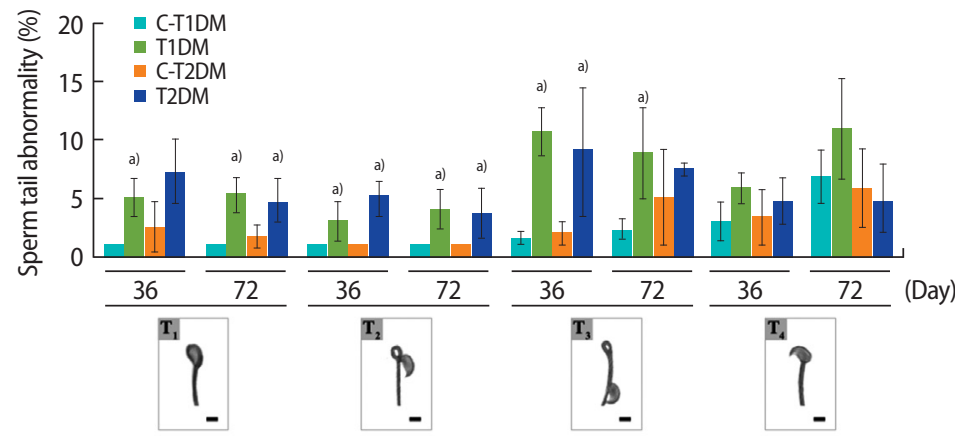

Figure 4. The percentages of individual types of abnormal sperm morphology compared among type 1 diabetes mellitus control (C-T1DM), type 1 DM (T1DM), type 2 DM control (C-T2DM), and type 2 DM (T2DM) mice on experimental days 36 and 72. (A) Abnormalities of the head. (B) Abnormalities of the tail. Values are presented as mean \pm standard deviation. Scale bar, $1 \mu \mathrm{m}$. $\mathrm{H}_{1}$, thin-elongated head; $\mathrm{H}_{2}$, club-shaped head; $\mathrm{H}_{3}$, mild head defects; $T_{1}$, bent head; $T_{2}$, looping midpiece; $T_{3}$, folded midpiece and principal piece; $T_{4}$, incorrect head-neck connection. ${ }^{a} p<0.05$ compared with controls.

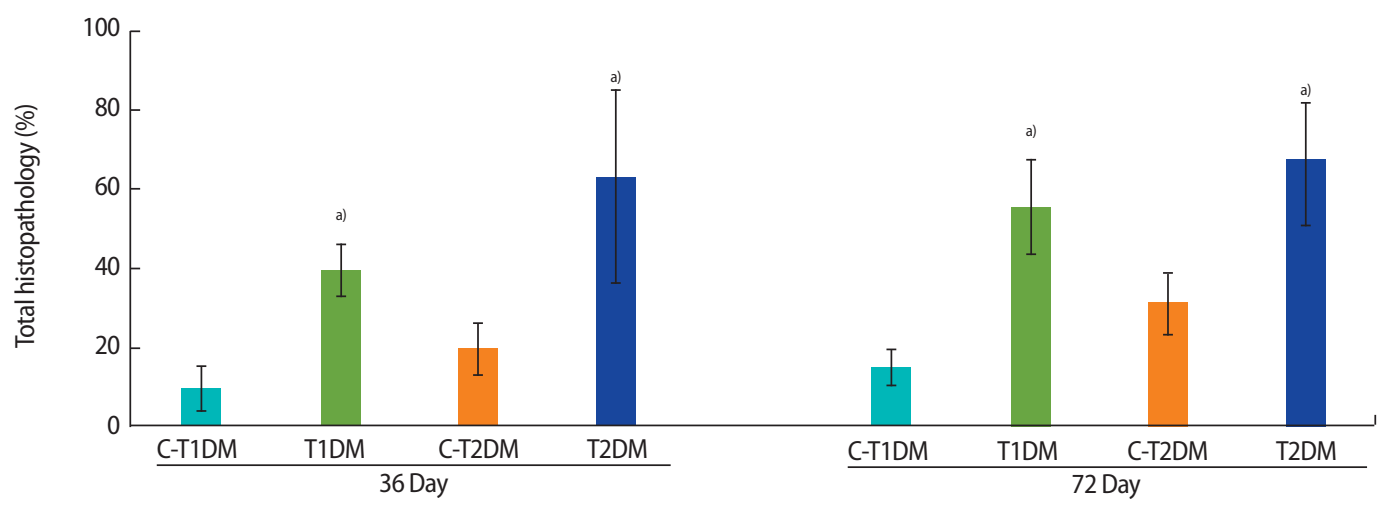

Figure 5. Seminiferous histopathology of the testis (\%) compared among type 1 diabetes mellitus control (C-T1DM), type 1 DM (T1DM), type 2 DM control (C-T2DM), and type 2 DM (T2DM) mice on experimental days 36 and 72. Values are presented as mean \pm standard deviation. ${ }^{a} p<0.05$ compared with controls.

(Figure 5) but did not differ significantly between the DM groups. Seminiferous histopathology was classified into seven types and compared among groups (Figure 6A). As shown in Figure 6Aa, the seminiferous epithelium was well-organized in all groups. By contrast, the DM groups displayed a significantly greater amount of sloughing of deciduous spermatogenic cells into the lumen compared to the controls (Figure 6Bb). The number of seminiferous epithelial cells with large nuclei was also significantly higher in the DM groups than in the controls and in the T1DM group than in the T2DM group on both days 36 and 72 (Figure 6Bc). The DM groups also displayed a significantly higher number of small-nucleus cells with vacuolization (Figure 6Bd), fewer layers of spermatogenic cells, and greater sloughing of germ cell elements into the seminiferous lumen (Figure 6Be) than the controls. There were greater numbers of cells of both histopathological types in the MLD-STZ group than in the HFDSTZ group at 36 days, but there were conversions between the 2 types within 72 days (Figure $6 \mathrm{Bd}$ and e). The T2DM group also dis- played more vacuolization in Sertoli cells without spermatids than the controls (Figure 6Bf). Moreover, atrophic tubular cells with germ cell degeneration and vacuolization were observed (Figure 6Ag). Reduction of the germinal epithelium (Figure 6Bh) was also significantly more prevalent in the T2DM group than in the controls. All the histopathological findings observed in the T2DM group were significantly more pronounced than in the T1DM group $(p<0.05)$ (Figure 6Bg and $h$ ).

\section{Histology of the epididymis}

The lumens of the caput, corpus, and caudal epididymides contained a greater percentage of round cells in both DM groups than in the control groups (Figure 7). The numbers of round germ cells at 72 days were higher than at 36 days (Figure 7). The density of sperm mass in the epididymal lumen of the T1DM and T2DM groups were lower than those controls (Figure 7), which corroborated with the significant decrease in sperm concentration shown in Figure 2A. 
A
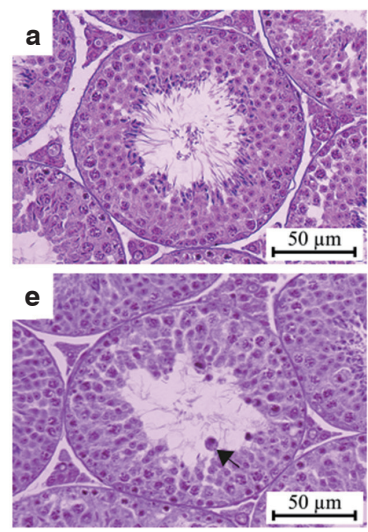
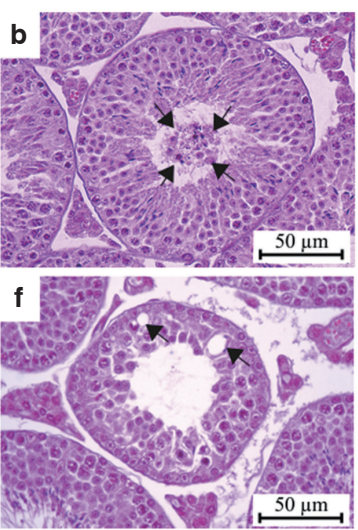
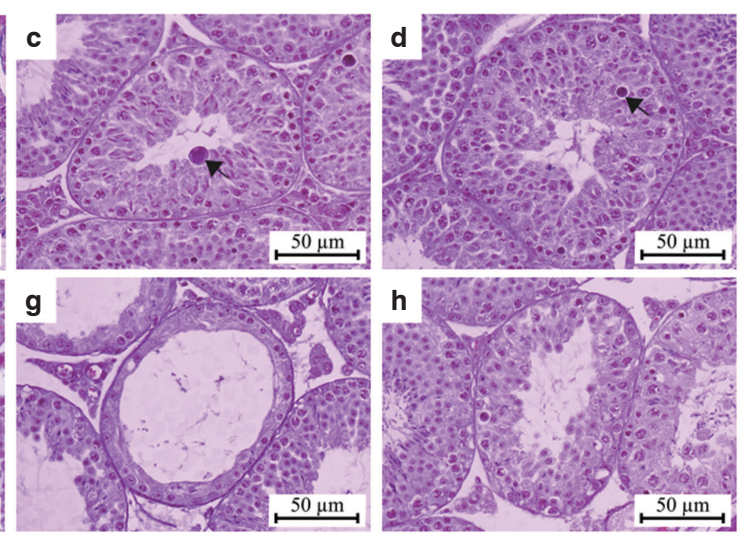

B

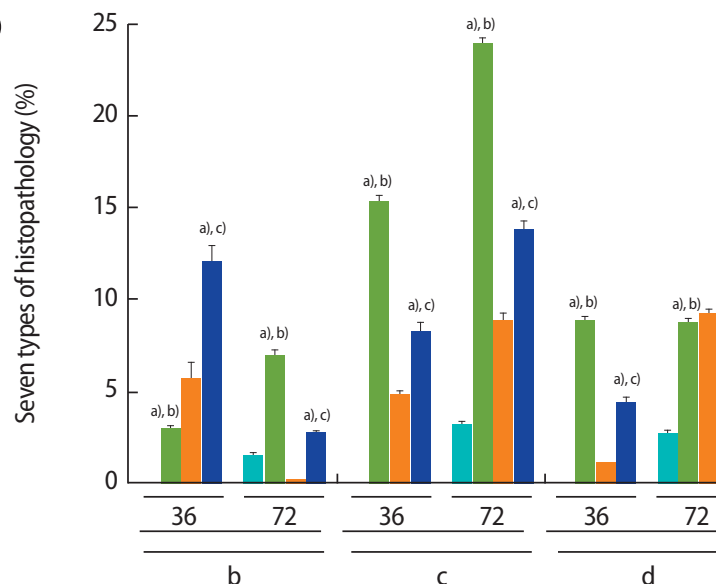

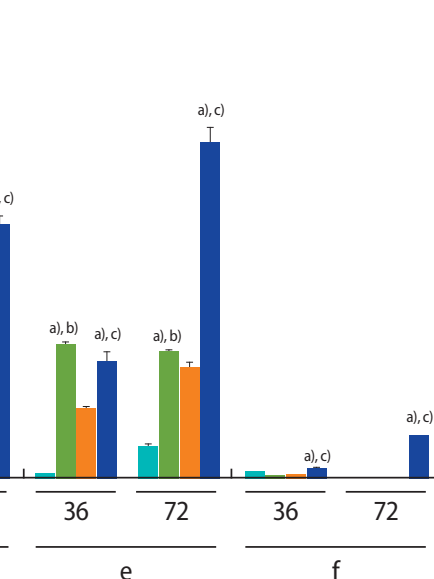

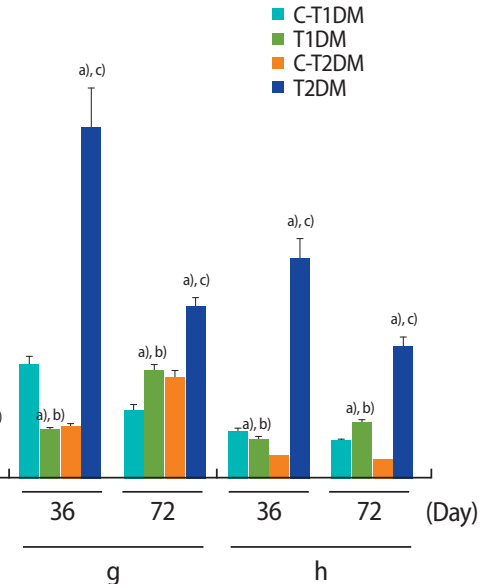

Figure 6. (A) Representative photomicrographs showing normal histology and histopathology. (a) Control group; normal arrangement of spermatogenic and Sertoli cells. (b-h) Histopathological findings of the seminiferous tubules found in the type 1 and type 2 diabetes mellitus (T1DM and T2DM) groups. (b) Sloughing of deciduous and spermatogenic cells (arrows) into the tubular lumen. (c) Cell with large nuclei (arrow) in the seminiferous epithelium. (d) Cell with small nuclei and vacuolization (arrow) in the seminiferous epithelium. (e) Few spermatogenic cell layers of artifactual sloughing (arrow) of germ cell elements into the lumen. (f) Vacuolization (arrows) of Sertoli cells and absence of spermatids. (g) Atrophy with germ cell degeneration and small vacuolization between spermatogonia and Sertoli cells. (h) Hypospermatogenesis with all germ layers diminished. (B) Seven histopathology types by percentage. Values are presented as mean \pm standard deviation. C-T1DM, type 1 diabetes mellitus control; C-T2DM, type 2 DM control. ${ }^{\text {al) }} p<0.05$ compared with controls; ${ }^{\text {b) }} p<0.05$ compared with T2DM; ${ }^{c} p<0.05$ compared with T1DM.

\section{Histomorphometry of seminiferous tubules}

The diameter and epithelial height of seminiferous tubules were significantly lower in the DM groups than in the controls $(p<0.05)$ (Figure 8). Furthermore, the thickness of the tunica albuginea was significantly greater at day 36 and had increased to a greater extent at day 72 in the DM groups than in the controls $(p<0.05)$ (Figure 9).

\section{Penile histomorphometry}

The percentage of the penile cross-sectional area in the T1DM and T2DM groups was significantly lower at 36 days and were slightly lower at 72 days compared to the controls $(p<0.05)$ (Figure 10). As shown in Figure 11A, the amount of collagen fibers of the penis was greater in both DM groups than in the controls. Similarly, the per- centage of penile collagen fibers was significantly higher in the DM groups than in the controls $(p<0.05)$ (Figure 11B).

\section{Discussion}

Recent studies have found decreases in the weights of male reproductive organs of animals with DM [5,36-38]. Chronic DM may induce oxidative stress, leading to damage to male reproductive structures and functions [39-41]. Although the seminiferous histopathology of T1DM mice has been described elsewhere [23], this study is the first to compare these histopathological parameters by DM type. In T1DM mice, the prevalence of histopathology by type at 36 days was e $>c>d>b>g>h$, and the prevalence was types $c>b>e>d>g>h$ at 72 days. In T2DM mice, the prevalence was types $h>g>d>f>b>c=e$ at 36 days, and it was 


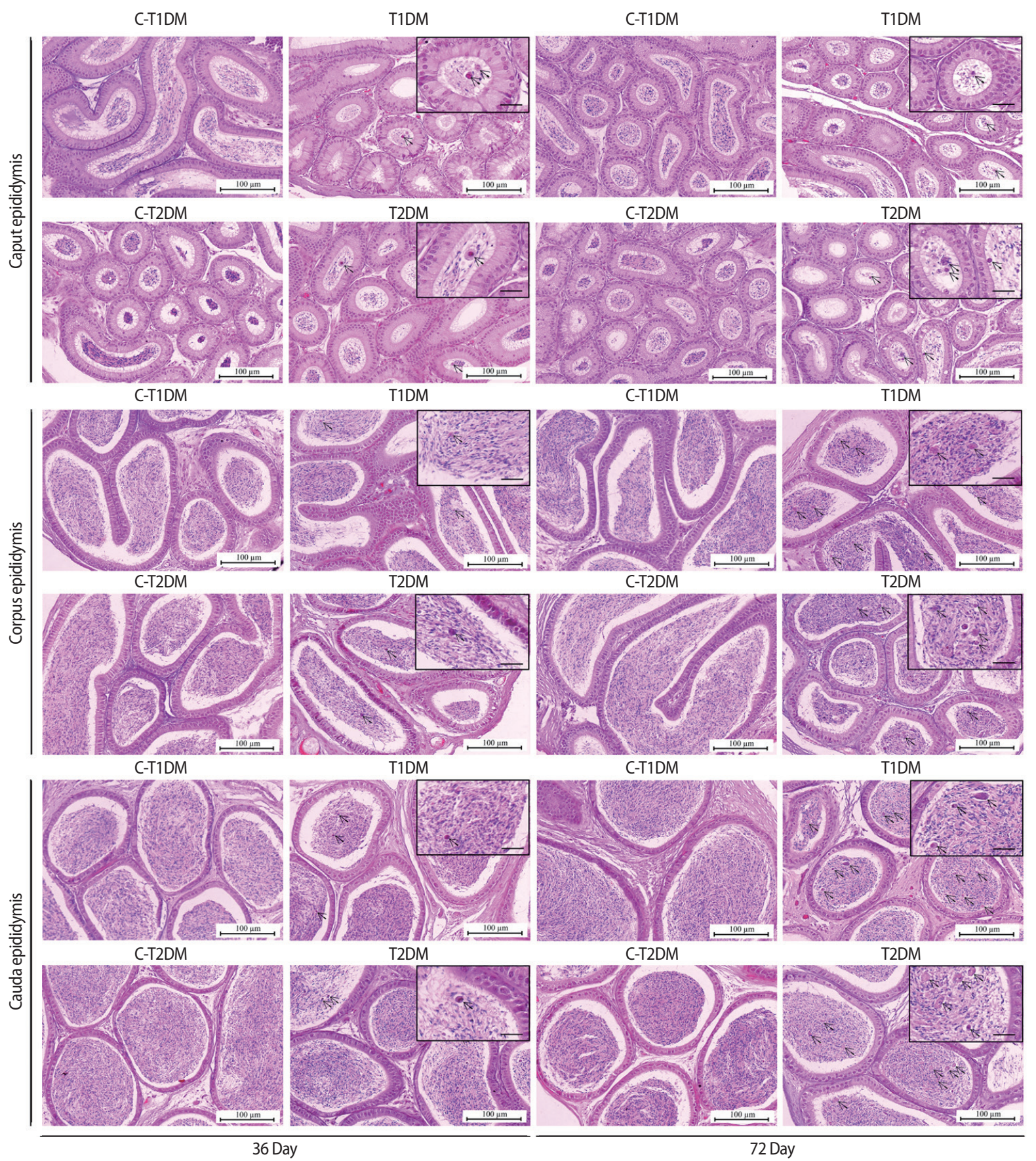

Figure 7. Representative histology of caput, corpus, and caudal epididymides of type 1 diabetes mellitus control (C-T1DM), type 1 DM (T1DM), type 2 DM control (C-T2DM), and type 2 DM (T2DM) mice on experimental days 36 and 72 . Arrows indicate the round germ cells in the epididymal lumen (small panels; scale bar, $20 \mu \mathrm{m}$ ).

types $b>h>e>f>g>c>d$ at 72 days. The decreases in diameter and epithelial height of the seminiferous tubules of T1DM and T2DM mice in our study were similar to those found in previous reports [23,38,4244]. Our study also found a positive correlation between seminiferous tubule diameter and spermatogenesis along with decreased sperm concentration in the T1DM and T2DM mice. The abundance of round cells found in the epididymal lumens of DM mice was also consistent with previous reports $[23,45]$ and may result from germ cell loss from the seminiferous epithelium $[46,47]$. The increase of collagen fibers in the tunica albuginea of the penis in T1DM and T2DM mice found in this study was also similar to previous studies $[48,49]$. Consistent with a previous report [50], the penile cross-sectional area (\%) was decreased in DM mice, resulting in atrophy of the penis. The increase of collagen fibers in the testis of animals with DM 


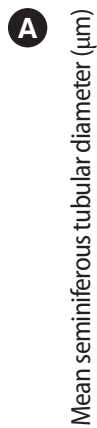

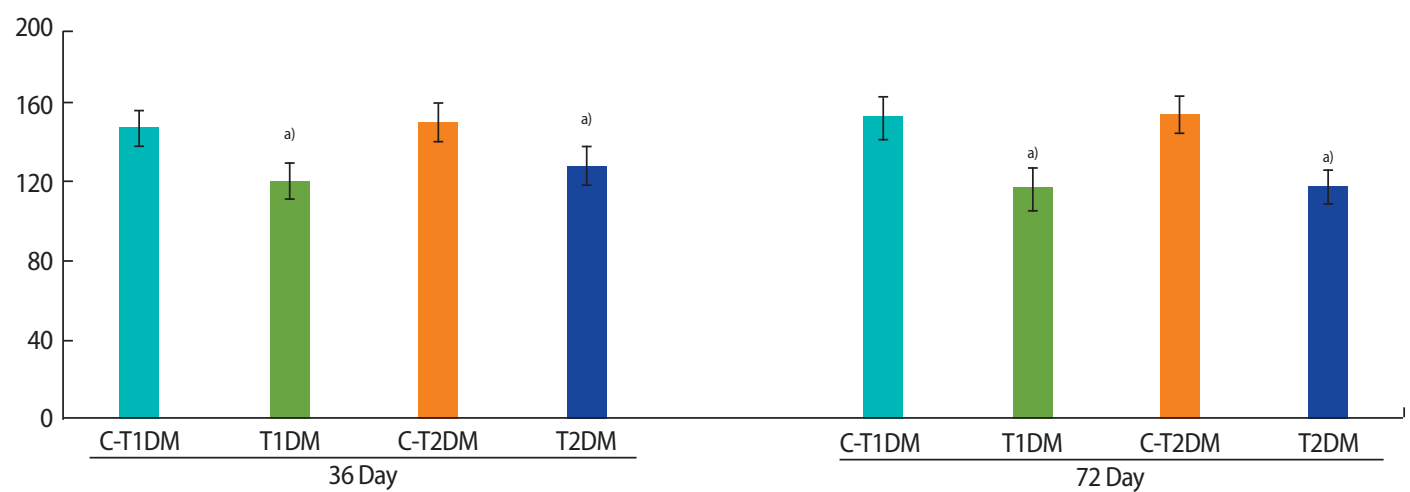

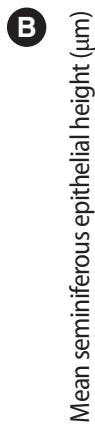

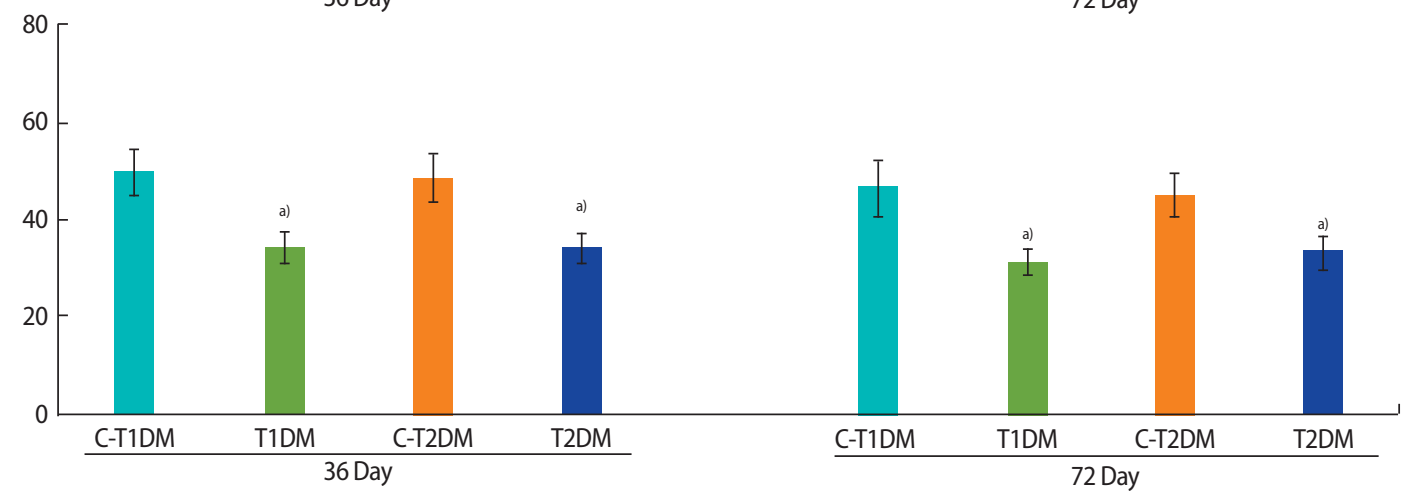

Figure 8. Histomorphometric analysis of seminiferous tubular diameter (A) and epithelial height (B) compared among type 1 diabetes mellitus control (C-T1DM), type 1 DM (T1DM), type 2 DM control (C-T2DM), and type 2 DM (T2DM) mice on experimental days 36 and 72 . Values are presented as mean \pm standard deviation. ${ }^{\text {a) }} p<0.05$ compared with controls.

A
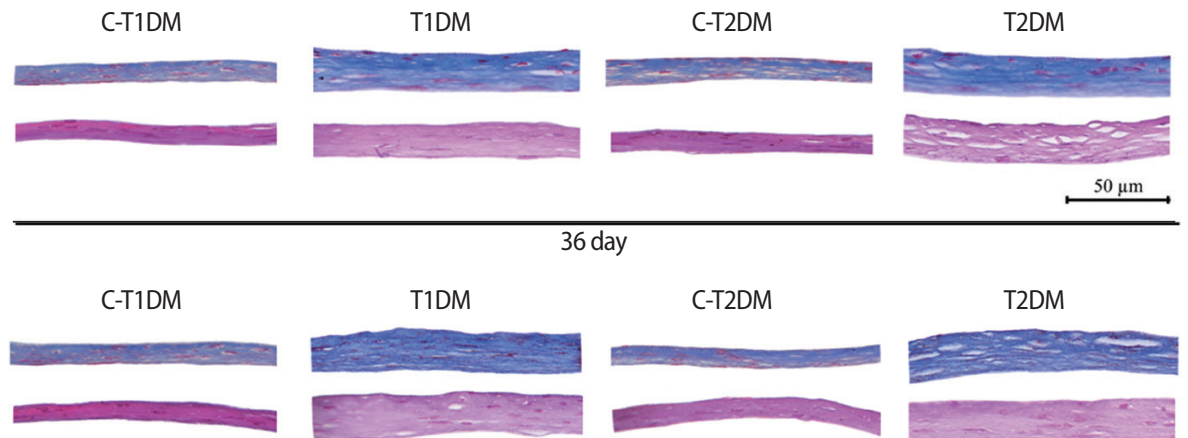

36 day

T1DM

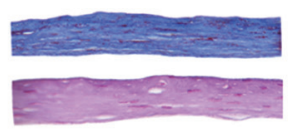

C-T2DM
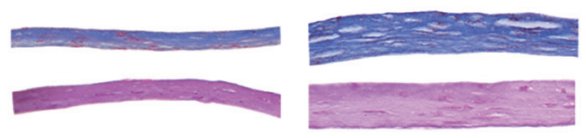

$50 \mu \mathrm{m}$

B

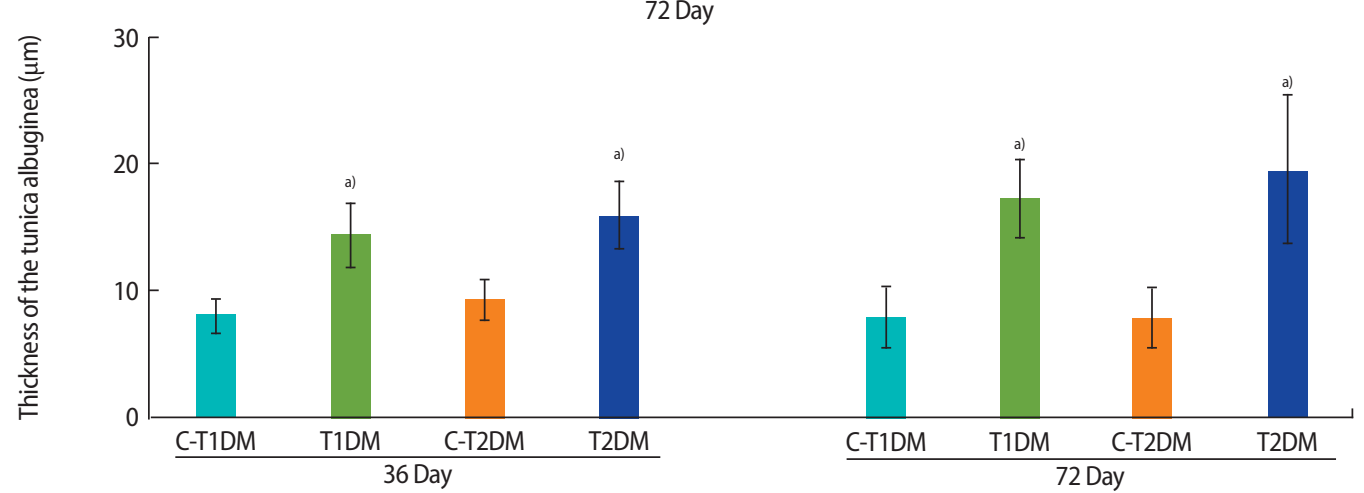

Figure 9. Representative histology of tunica albuginea stained by H\&E (lower panels) and Masson's trichrome (upper panels; A) and thickness (B) compared among type 1 diabetes mellitus control (C-T1DM), type 1 DM (T1DM), type 2 DM control (C-T2DM), and type 2 DM (T2DM) mice on experimental days 36 and 72 . Values are presented as mean \pm standard deviation. ${ }^{\text {al) }} p<0.05$ compared with controls. 
A

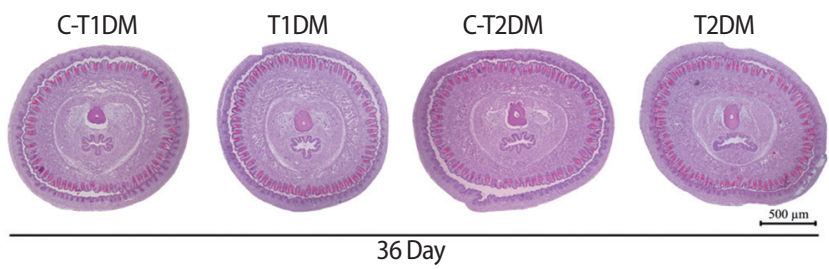

B
36 Day

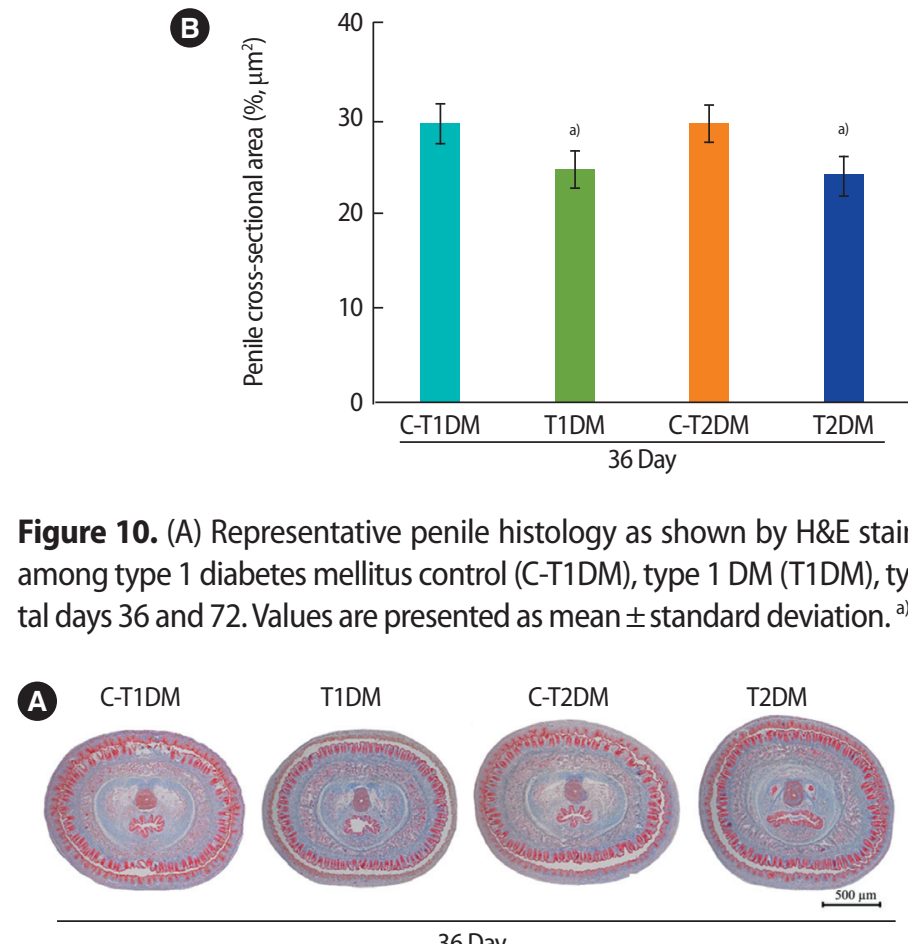

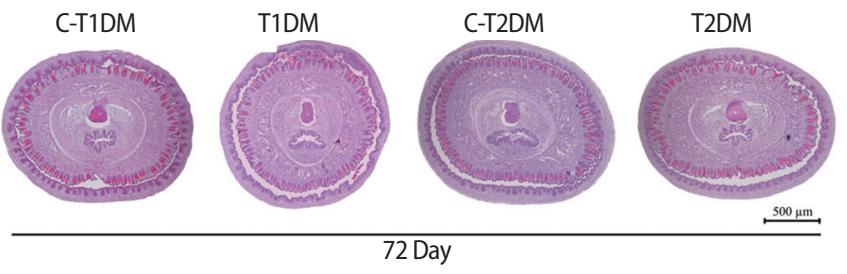

72Day

Figure 10. (A) Representative penile histology as shown by H\&E staining and (B) percentage of the penile cross-sectional area compared among type 1 diabetes mellitus control (C-T1DM), type 1 DM (T1DM), type 2 DM control (C-T2DM), and type 2 DM (T2DM) mice on experimental days 36 and 72 . Values are presented as mean \pm standard deviation. ${ }^{\text {al }} p<0.05$ compared with controls.

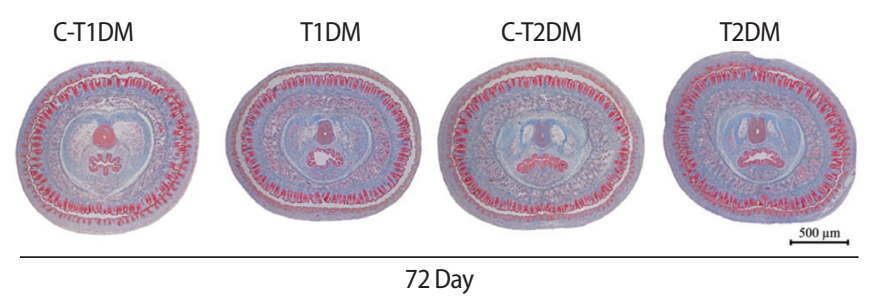

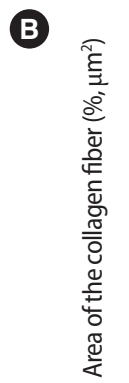

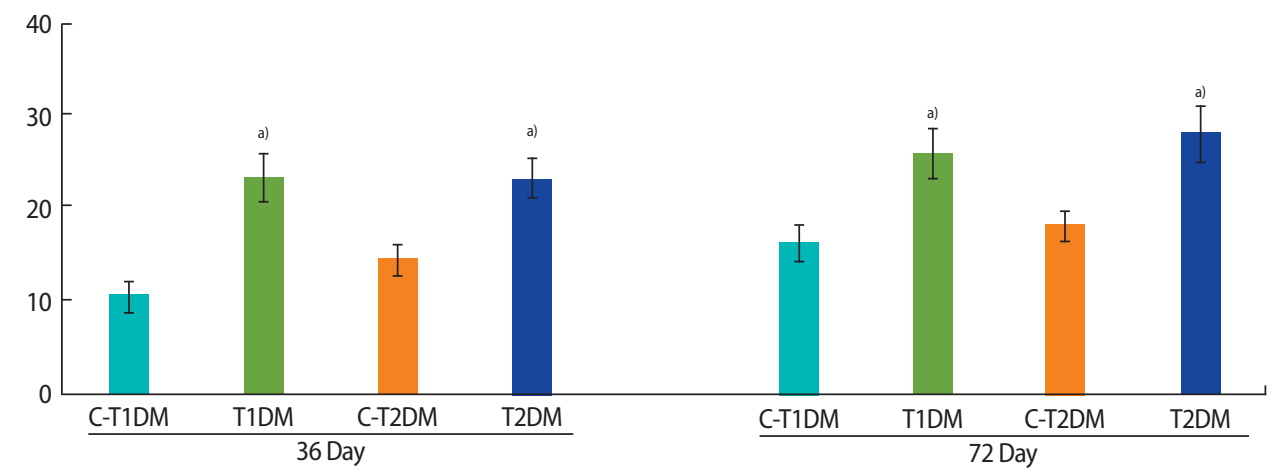

Figure 11. (A) Penile collagen fibers stained using Masson trichrome and (B) percentage of collagen fiber area compared among type 1 DM control (C-T1DM), type 1 DM (T1DM), type 2 DM control (C-T2DM), and type 2 DM (T2DM) mice on experimental days 36 and 72 . Values are presented as mean \pm standard deviation. ${ }^{\text {a) }} p<0.05$ compared with controls.

may have been caused by increased expression of transforming growth factor beta 1 and nitric oxide synthase [51-54].

Similar to our study, previous studies have demonstrated decreases of sperm concentration in DM human and animal models $[5,6,37$, $42,55-58]$, which may be due to impaired spermatogenesis $[5,6,12,57,59-61]$. The increase of total abnormal sperm morphology in both groups of DM mice in our study was consistent with the find- ings of previous studies $[23,37,42,62-65]$. It is possible that DM affects the regulation of some proteins involved in the formation of sperm structures, such as hook microtubule tethering protein 1 (Hook1) and disintegrin and metalloprotease 7 (ADAM7) [60,66-68]. Additionally, DM-induced oxidative stress may cause nondisjunction, mitochondrial DNA damage, and defective centriole migration in germ cells $[64,69]$. Increased amounts of AR sperm have been found in animals 
exposed to various induction methods, including HFD, drugs, or stressors [23,31,32,70-72]. The significant decrease of testicular nerve growth factor levels in DM animals $[73,74]$ implies that the impairment of AR formation by DM affects regulation via the testicular nerve growth factor signaling pathway $[74,75]$. Several studies have shown increases of sperm with fragmented nuclear DNA in men with DM $[10,76,77]$. In the present study, the increase in sperm with damaged DNA in mice with DM was greater than in previous studies $[34,78]$. It is possible that chromatin decondensation and sperm DNA fragmentation are more sensitive in animal DM models [10,34,71]. However, there was no significant difference in the percentage of $A B-$ positive sperm cells in our study, similarly to previous reports $[34,78]$. Although DM may not affect chromatin packaging, it is correlated with sperm morphology [34,79].

This study reported that T1DM and T2DM mice were similar in terms of nearly all adverse reproductive parameters, but that the severity of the reduction in sperm concentration and precocious acrosome exocytosis was greater in those with T1DM.

\section{Conflict of interest}

No potential conflict of interest relevant to this article was reported.

\section{ORCID}

Apichakan Sampannang https://orcid.org/0000-0003-4929-6386

Supatcharee Arun

Jaturon Burawat

Wannisa Sukhorum

https://orcid.org/0000-0002-7518-2406

https://orcid.org/0000-0002-7856-5891

Sitthichai lamsaard

https://orcid.org/0000-0003-3327-5636

https://orcid.org/0000-0002-6793-2879

\section{Author contributions}

Conceptualization: AS and SI. Data curation: SA and AS. Formal analysis:WS and AS. Funding acquisition: SI. Methodology: AS, JB, SA, and WS. Project administration: SI. Visualization: AS and SI. Writing original draft: AS. Writing - review \& editing: SI.

\section{References}

1. Report of the Expert Committee on the Diagnosis and Classification of Diabetes Mellitus. Diabetes Care 1997;20:1183-97.

2. American Diabetes Association. Diagnosis and classification of diabetes mellitus. Diabetes Care 2013;36 Suppl 1:S67-74.

3. American Diabetes Association. Diagnosis and classification of diabetes mellitus. Diabetes Care 2009;32 Suppl 1:S62-7.

4. Frier BM, Fisher M. Diabetes mellitus. In: Colledge NR, Walker BR,
Ralston S, Davidson S, editors. Davidson's principles and practice of medicine. India: Elsevier; 2010. p. 735.

5. Ahangarpour A, Oroojan AA, Heidari H, Ghaedi E, Taherkhani R. Effects of hydro-alcoholic extract from Arctium lappa L. (Burdock) root on gonadotropins, testosterone, and sperm count and viability in male mice with nicotinamide/streptozotocin-induced type 2 diabetes. Malays J Med Sci 2015;22:25-32.

6. Ahangarpour A, Oroojan AA, Khorsandi L, Arzani G, Afshari G. Effects of betulinic acid on the male reproductive system of a streptozotocin-nicotinamide-induced diabetic mouse model. World J Mens Health 2016;34:209-16.

7. Alves MG, Martins AD, Moreira PI, Carvalho RA, Sousa M, Barros A, et al. Metabolic fingerprints in testicular biopsies from type $1 \mathrm{di}-$ abetic patients. Cell Tissue Res 2015;362:431-40.

8. Ding GL, Liu Y, Liu ME, Pan JX, Guo MX, Sheng JZ, et al. The effects of diabetes on male fertility and epigenetic regulation during spermatogenesis. Asian J Androl 2015;17:948-53.

9. Cai L, Chen S, Evans T, Deng DX, Mukherjee K, Chakrabarti S. Apoptotic germ-cell death and testicular damage in experimental diabetes: prevention by endothelin antagonism. Urol Res 2000;28:342-7.

10. Agbaje IM, Rogers DA, McVicar CM, McClure N, Atkinson AB, Mallidis $C$, et al. Insulin dependant diabetes mellitus: implications for male reproductive function. Hum Reprod 2007;22:1871-7.

11. Alves MG, Martins AD, Cavaco JE, Socorro S, Oliveira PF. Diabetes, insulin-mediated glucose metabolism and Sertoli/blood-testis barrier function. Tissue Barriers 2013;1:e23992.

12. Xu Y, Lei H, Guan R, Gao Z, Li H, Wang L, et al. Studies on the mechanism of testicular dysfunction in the early stage of a streptozotocin induced diabetic rat model. Biochem Biophys Res Commun 2014:450:87-92.

13. Zha W, Bai Y, Xu L, Liu Y, Yang Z, Gao H, et al. Curcumin attenuates testicular injury in rats with streptozotocin-induced diabetes. Biomed Res Int 2018;2018:7468019.

14. Yanagimachi R, Usui N. Calcium dependence of the acrosome reaction and activation of guinea pig spermatozoa. Exp Cell Res 1974;89:161-74.

15. Menkveld R, Holleboom CA, Rhemrev JP. Measurement and significance of sperm morphology. Asian J Androl 2011;13:59-68.

16. Venkatesh S, Gurdeep Singh MP, Prasad Gupta N, Kumar R, Deecaraman $\mathrm{M}$, et al. Correlation of sperm morphology and oxidative stress in infertile men. Iran J Reprod Med 2009;7:29-34.

17. Carrell DT, Emery BR, Hammoud S. Altered protamine expression and diminished spermatogenesis: what is the link? Hum Reprod Update 2007;13:313-27.

18. Talebi AR, Vahidi S, Aflatoonian A, Ghasemi N, Ghasemzadeh J, Firoozabadi RD, et al. Cytochemical evaluation of sperm chroma- 
tin and DNA integrity in couples with unexplained recurrent spontaneous abortions. Andrologia 2012;44 Suppl 1:462-70.

19. Ventura-Sobrevilla J, Boone-Villa VD, Aguilar CN, Roman-Ramos $\mathrm{R}$, Vega-Avila E, Campos-Sepulveda E, et al. Effect of varying dose and administration of streptozotocin on blood sugar in male CD1 mice. Proc West Pharmacol Soc 2011;54:5-9.

20. Li X, Xu Z, Jiang Z, Sun L, Ji J, Miao J, et al. Hypoglycemic effect of catalpol on high-fat diet/streptozotocin-induced diabetic mice by increasing skeletal muscle mitochondrial biogenesis. Acta Biochim Biophys Sin (Shanghai) 2014;46:738-48.

21. Mali VR, Ning R, Chen J, Yang XP, Xu J, Palaniyandi SS. Impairment of aldehyde dehydrogenase- 2 by 4-hydroxy-2-nonenal adduct formation and cardiomyocyte hypertrophy in mice fed a high-fat diet and injected with low-dose streptozotocin. Exp Biol Med (Maywood) 2014;239:610-8.

22. Sampannang A, Arun S, Sukhorum W, Burawat J, Nualkaew S, Maneenin C, et al. Antioxidant and hypoglycemic effects of Momordica cochinchinensis Spreng: (Gac) aril extract on reproductive damages in streptozotocin (STZ)-induced hyperglycemia mice. Int J Morphol 2017;35:667-75.

23. Sampannang A, Arun S, Burawat J, Sukhorum W, lamsaard S. Testicular histopathology and phosphorylated protein changes in mice with diabetes induced by multiple-low doses of streptozotocin: an experimental study. Int J Reprod Biomed (Yazd) 2018;16:235-46.

24. Rossini AA, Williams RM, Appel MC, Like AA. Complete protection from low-dose streptozotocin-induced diabetes in mice. Nature 1978;276:182-4.

25. Chaudhry ZZ, Morris DL, Moss DR, Sims EK, Chiong Y, Kono T, et al. Streptozotocin is equally diabetogenic whether administered to fed or fasted mice. Lab Anim 2013;47:257-65.

26. Reed MJ, Meszaros K, Entes L, Claypool MD, Pinkett JG, Gadbois TM, et al. A new rat model of type 2 diabetes: the fat-fed, streptozotocin-treated rat. Metabolism 2000;49:1390-4.

27. Srinivasan K, Viswanad B, Asrat L, Kaul CL, Ramarao P. Combination of high-fat diet-fed and low-dose streptozotocin-treated rat: a model for type 2 diabetes and pharmacological screening. Pharmacol Res 2005;52:313-20.

28. Zhang M, Lv XY, Li J, Xu ZG, Chen L. The characterization of highfat diet and multiple low-dose streptozotocin induced type 2 diabetes rat model. Exp Diabetes Res 2008;2008:704045.

29. Bose R, Adiga SK, D'Souza F, Salian SR, Uppangala S, Kalthur G, et al. Germ cell abnormalities in streptozotocin induced diabetic mice do not correlate with blood glucose level. J Assist Reprod Genet 2012;29:1405-13.

30. Ward MA. Intracytoplasmic sperm injection effects in infertile azh mutant mice. Biol Reprod 2005;73:193-200.
31. Arun S, Burawat J, Sukhorum W, Sampannang A, Maneenin C, lamsaard $\mathrm{S}$. Chronic restraint stress induces sperm acrosome reaction and changes in testicular tyrosine phosphorylated proteins in rats. Int J Reprod Biomed (Yazd) 2016;14:443-52.

32. Sukhorum W, lamsaard S. Changes in testicular function proteins and sperm acrosome status in rats treated with valproic acid. Reprod Fertil Dev 2017;29:1585-92.

33. Amaral S, Oliveira PJ, Ramalho-Santos J. Diabetes and the impairment of reproductive function: possible role of mitochondria and reactive oxygen species. Curr Diabetes Rev 2008;4:4654.

34. Mangoli E, Talebi AR, Anvari M, Pourentezari M. Effects of experimentally-induced diabetes on sperm parameters and chromatin quality in mice. Iran J Reprod Med 2013;11:53-60.

35. Terquem T, Dadoune JP. Aniline blue staining of human spermatozoa chromatin: evaluation of nuclear maturation. In: Andre J, editor. The sperm cell. London: The Hague, Martinus Nijhoff; 1983. p. 249-52.

36. Soudamani S, Malini T, Balasubramanian K. Effects of streptozotocin-diabetes and insulin replacement on the epididymis of prepubertal rats: histological and histomorphometric studies. Endocr Res 2005;31:81-98.

37. Navarro-Casado L, Juncos-Tobarra MA, Chafer-Rudilla M, de Onzono LI, Blazquez-Cabrera JA, Miralles-Garcia JM. Effect of experimental diabetes and STZ on male fertility capacity: study in rats. J Androl 2010;31:584-92.

38. Long L, Wang J, Lu X, Xu Y, Zheng S, Luo C, et al. Protective effects of scutellarin on type II diabetes mellitus-induced testicular damages related to reactive oxygen species/BCl-2/Bax and reactive oxygen species/microcirculation/staving pathway in diabetic rat. J Diabetes Res 2015;2015:252530.

39. Ishii H, Jirousek MR, Koya D, Takagi C, Xia P, Clermont A, et al. Amelioration of vascular dysfunctions in diabetic rats by an oral PKC beta inhibitor. Science 1996;272:728-31.

40. Rahimi R, Nikfar S, Larijani B, Abdollahi M. A review on the role of antioxidants in the management of diabetes and its complications. Biomed Pharmacother 2005;59:365-73.

41. Mohasseb M, Ebied S, Yehia MA, Hussein N. Testicular oxidative damage and role of combined antioxidant supplementation in experimental diabetic rats. J Physiol Biochem 2011;67:185-94.

42. Fernandes GS, Fernandez CD, Campos KE, Damasceno DC, Anselmo-Franci JA, Kempinas WD. Vitamin C partially attenuates male reproductive deficits in hyperglycemic rats. Reprod Biol Endocrinol 2011;9:100.

43. Khaneshi F, Nasrolahi O, Azizi S, Nejati V. Sesame effects on testicular damage in streptozotocin-induced diabetes rats. Avicenna J Phytomed 2013;3:347-55. 
44. Donmez YB, Kizilay G, Topcu-Tarladacalisir Y. MAPK immunoreactivity in streptozotocin-induced diabetic rat testis. Acta Cir Bras 2014;29:644-50.

45. Amaral S, Mota PC, Lacerda B, Alves M, Pereira Mde L, Oliveira PJ, et al. Testicular mitochondrial alterations in untreated streptozotocin-induced diabetic rats. Mitochondrion 2009;9:41-50.

46. Creasy DM. Pathogenesis of male reproductive toxicity. Toxicol Pathol 2001;29:64-76.

47. Vidal JD, Whitney KM. Morphologic manifestations of testicular and epididymal toxicity. Spermatogenesis 2014;4:e979099.

48. Jelodar G, Khaksar Z, Pourahmadi M. Endocrine profile and testicular histomorphometry in neonatal rats of diabetic mothers. Vet Arh 2009;80:421-30.

49. Mohamed AK, Zaahkouk S, Abo-Elnaga N, Mousa E. Ameliorating effect of olive leaf extract on testes of diabetic young male rats: histopathological and hematological studies. Adv Biol Res 2017;11:56-63.

50. Tao M, Tasdemir C, Tasdemir S, Shahabi A, Liu G. Penile alterations at early stage of type 1 diabetes in rats. Int Braz J Urol 2017;43:753-61.

51. Davila HH, Magee TR, Vernet D, Rajfer J, Gonzalez-Cadavid NF. Gene transfer of inducible nitric oxide synthase complementary DNA regresses the fibrotic plaque in an animal model of Peyronie's disease. Biol Reprod 2004;71:1568-77.

52. Gonzalez-Cadavid NF, Rajfer J. Mechanisms of disease: new insights into the cellular and molecular pathology of Peyronie's disease. Nat Clin Pract Urol 2005;2:291-7.

53. Mou X, Zhou DY, Zhou DY, Ma JR, Liu YH, Chen HP, et al. Serum TGF- $\beta 1$ as a biomarker for type 2 diabetic nephropathy: a metaanalysis of randomized controlled trials. PLoS One 2016;11: e0149513.

54. Sonmez MF, Kilic E, Karabulut D, Cilenk K, Deligonul E, Dundar M. Nitric oxide synthase in diabetic rat testicular tissue and the effects of pentoxifylline therapy. Syst Biol Reprod Med 2016;62:2230.

55. Kim ST, Moley KH. Paternal effect on embryo quality in diabetic mice is related to poor sperm quality and associated with decreased glucose transporter expression. Reproduction 2008;136: 313-22.

56. Butchi Akondi R, Kumar P, Annapurna A, Pujari M. Protective effect of rutin and naringin on sperm quality in streptozotocin (STZ) induced type 1 diabetic rats. Iran J Pharm Res 2011;10:58596.

57. Liu GL, Zhang YM, Dai DZ, Ding MJ, Cong XD, Dai Y. Male hypogonadism induced by high fat diet and low dose streptozotocin is mediated by activated endoplasmic reticulum stress and $\mathrm{IKB}_{\mathrm{K}} \mathrm{B}$ and attenuated by argirein and valsartan. Eur J Pharmacol 2013;
713:78-88.

58. Singh AK, Tomarz S, Chaudhari AR, Sinqh R, Verma N. Type 2 diabetes mellitus affects male fertility potential. Indian J Physiol Pharmacol 2014;58:403-6.

59. Ballester J, Munoz MC, Dominguez J, Rigau T, Guinovart JJ, Rodriguez-Gil JE. Insulin-dependent diabetes affects testicular function by FSH- and LH-linked mechanisms. J Androl 2004;25: 706-19.

60. Kianifard D, Sadrkhanlou RA, Hasanzadeh S. The ultrastructural changes of the sertoli and leydig cells following streptozotocin induced diabetes. Iran J Basic Med Sci 2012;15:623-35.

61. Rato L, Alves MG, Dias TR, Cavaco JE, Oliveira PF. Testicular metabolic reprogramming in neonatal streptozotocin-induced type 2 diabetic rats impairs glycolytic flux and promotes glycogen synthesis. J Diabetes Res 2015;2015:973142.

62. Rabbani SI, Devi K, Khanam S. Pioglitazone, a PPAR-gamma ligand inhibited the nicotinamide-streptozotocin induced sperm abnormalities in type-2 diabetic Wistar rats. Pak J Pharm Sci 2010;23:326-31.

63. Hadi MA, Zaidan HK, Natah TM, Al-Saadi AH. Protective effect of plants extracts mixture on sperm abnormalities, testicular and epididymal tissues in diabetic male rats. J Nat Sci Res 2013;3:2837.

64. Kilarkaje N, Al-Hussaini H, Al-Bader MM. Diabetes-induced DNA damage and apoptosis are associated with poly (ADP ribose) polymerase 1 inhibition in the rat testis. Eur J Pharmacol 2014; 737:29-40.

65. Oliveira PF, Tomas GD, Dias TR, Martins AD, Rato L, Alves MG, et al. White tea consumption restores sperm quality in prediabetic rats preventing testicular oxidative damage. Reprod Biomed Online 2015;31:544-56.

66. Mendoza-Lujambio I, Burfeind P, Dixkens C, Meinhardt A, HoyerFender S, Engel W, et al. The Hook1 gene is non-functional in the abnormal spermatozoon head shape (azh) mutant mouse. Hum Mol Genet 2002;11:1647-58.

67. Yeung $\mathrm{CH}$, Tuttelmann F, Bergmann M, Nordhoff V, Vorona $\mathrm{E}$, Cooper TG. Coiled sperm from infertile patients: characteristics, associated factors and biological implication. Hum Reprod 2009;24:1288-95

68. Choi H, Han C, Jin S, Kwon JT, Kim J, Jeong J, et al. reduced fertility and altered epididymal and sperm integrity in mice lacking ADAM7. Biol Reprod 2015;93:70.

69. Narayana K, D'Souza UJ, Seetharama Rao KP. Ribavirin-induced sperm shape abnormalities in Wistar rat. Mutat Res 2002;513: 193-6.

70. Cheon YP, Cho HJ, Kim KS. Spermatozoa characteristics of streptozotocin-induced diabetic Zucker lean rat: calcium ionophore- 
induced acrosome reaction and sperm concentration. Korean J Lab Anim Sci 1998;14;15-20.

71. Cheon YP, Kim CH, Kang BM, Chang YS, Nam JH, Kim YS, et al. Spermatozoa characteristics of streptozotocin-induced diabetic Wistar rat: acrosome reaction and spermatozoa concentration. Korean J Fertil Steril 1999;26:89-96.

72. Fan Y, Liu Y, Xue K, Gu G, Fan W, Xu Y, et al. Diet-induced obesity in male C57BL/6 mice decreases fertility as a consequence of disrupted blood-testis barrier. PLoS One 2015;10:e0120775.

73. Ayer-LeLievre C, Olson L, Ebendal T, Hallbook F, Persson H. Nerve growth factor mRNA and protein in the testis and epididymis of mouse and rat. Proc Natl Acad Sci U S A 1988;85:2628-32.

74. Sisman AR, Kiray M, Camsari UM, Evren M, Ates M, Baykara B, et al. Potential novel biomarkers for diabetic testicular damage in streptozotocin-induced diabetic rats: nerve growth factor Beta and vascular endothelial growth factor. Dis Markers 2014;2014: 108106

75. Jin W, Tanaka A, Watanabe G, Matsuda H, Taya K. Effect of NGF on the motility and acrosome reaction of golden hamster sper- matozoa in vitro. J Reprod Dev 2010;56:437-43.

76. Ahmadi A, Fajri M, Sadrkhanlou RA, Mokhtari M. Evaluation of epididymal sperm quality, DNA damage and sperm maturation abnormality in streptozotocin-induced diabetic mice. Int J Fertil Steril 2011;5:40.

77. Paasch U, Heidenreich F, Pursche T, Kuhlisch E, Kettner K, Grunewald S, et al. Identification of increased amounts of eppin protein complex components in sperm cells of diabetic and obese individuals by difference gel electrophoresis. Mol Cell Proteomics 2011;10:M110.007187.

78. Talebi AR, Mangoli E, Nahangi H, Anvari M, Pourentezari M, Halvaei I. Vitamin $C$ attenuates detrimental effects of diabetes mellitus on sperm parameters, chromatin quality and rate of apoptosis in mice. Eur J Obstet Gynecol Reprod Biol 2014;181: 32-6.

79. Kim HS, Kang MJ, Kim SA, Oh SK, Kim H, Ku SY, et al. The utility of sperm DNA damage assay using toluidine blue and aniline blue staining in routine semen analysis. Clin Exp Reprod Med 2013; 40:23-8. 